\title{
En eksplosiv historie
}

De fleste ulykker skjer i hjemmet, så også for denne gårdbrukeren som skulle lage en blanding som var blitt laget på samme måte i ca. 40 år - uten uhell (Tidsskr Nor Lægeforen 1916; 36: 53). Han ble hardt skadet, men overlevde heldigvis. Historien var så «god» at redaksjonen i Tidsskriftet så seg nødt til å komme med en liten kommentar.

\section{En kraftig hestesmørje}

\section{Av R. M Bergh, Vadheim.}

Forleden blev jeg hentet til en gaardbruker, som var blit haardt skadet ved en eksplosion, som hadde indtruffet, da han holdt paa at lage en hestesmørje.

Under sammenblandingen paa $1 / 2$ ølflaske indtraf eksplosionen, som sprængte flasken med saadan kraft, at glasbiterne trængte igjennem vest og skjorte og hadde skaaret ind gjennem huden paa brystet, hvor der var otte 2 til 3 centimeter lange saar. Paa halsen var der et temmelig dypt og langt saar i nærheten av de store aarer. I ansigtet var der ogsaa nogen saar, likesaa paa hænderne og armene. - Glasbiterne hadde knust nogen ruter og skrapet store merker i væggene.

Ogsaa en anden tilstedeværende person blev skadet paa armene.

Manden fortalte, at han i lange tider hadde laget denne smørje, som stod i høi kurs, da dype saar paa hester tilhelet hurtig efter den.

Blandingen bestaar av digerolje (birkennæverolje, pyrol. betulin.) og tegelstenolje (ol. philsoph.) samt salpetersyre.

Som ovenstaaende tilfælde viser er altsaa blandingen i høi grad eksplosiv, men merkelig nok kjente han ikke til, at den før hadde eksplodert, uagtet den i hans hus var tillaget i omtrent $40 \mathrm{aar}^{1}$ ).

1) Er der ikke en mulighet for, at flasken kan ha indeholdt rester av en glycerinholdig væske og at der saaledes har dannet sig nitroglycerin?

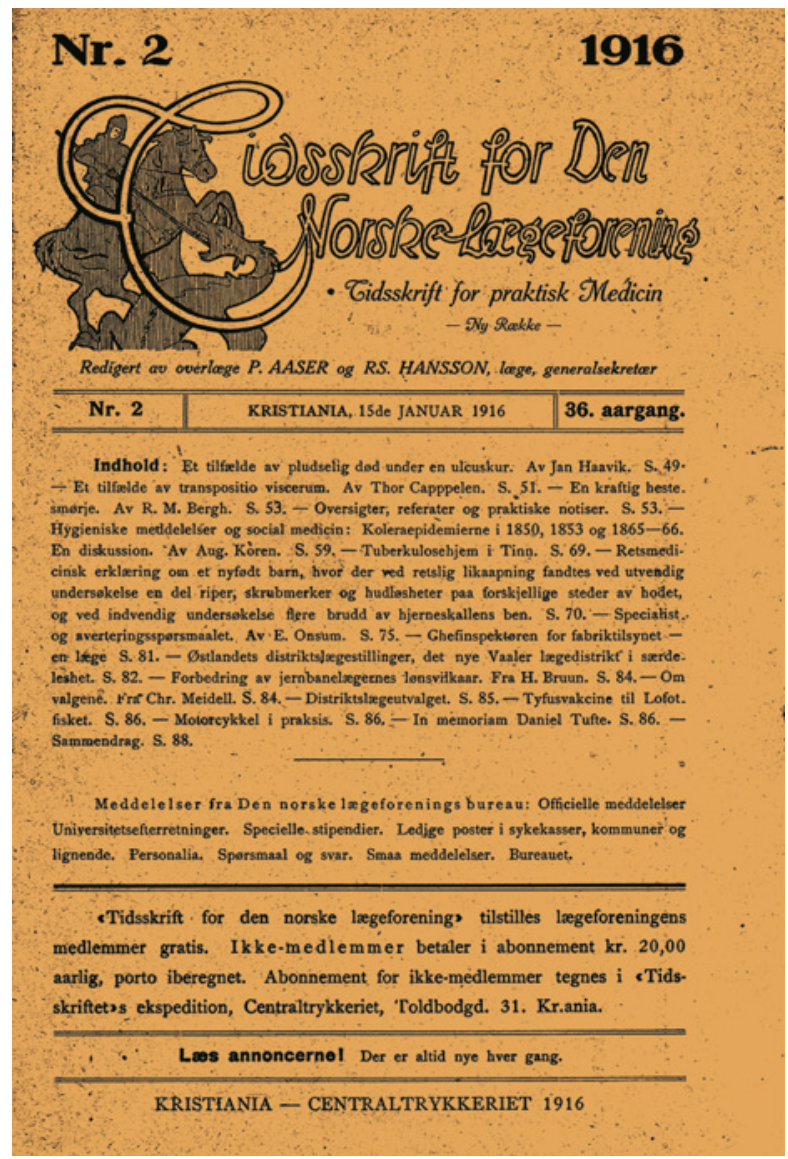

